This PDF is a selection from a published volume from the National Bureau of Economic Research

Volume Title: Frontiers in Health Policy Research, Volume 6

Volume Author/Editor: David M. Cutler and Alan M. Garber, editors

Volume Publisher: MIT Press

Volume ISBN: 0-262-03309-7

Volume URL: http://www.nber.org/books/cutl03-1

Conference Date: May 29, 2002

Publication Date: January 2003

Title: The Impact of Macroeconomic Conditions on the Health Insurance Coverage of Americans

Author: John Cawley, Kosali I. Simon

URL: http://www.nber.org/chapters/c9865 


\section{The Impact of Macroeconomic Conditions on the Health Insurance Coverage of Americans}

John Cawley Cornell University and NBER

Kosali I. Simon Cornell University and NBER

\section{Executive Summary}

In March 2001, the longest economic expansion in U.S. history ended, and an economic recession began. This paper seeks to provide a better understanding of the historical relationship between macroeconomic variables and health insurance coverage.

We use data from two nationally representative samples: the Survey of Income and Program Participation (SIPP) and the National Longitudinal Survey of Youth (NLSY). The longitudinal nature of our data allows us to remove individual-specific, time-invariant heterogeneity and to focus on changes in health insurance status in response to changes in macroeconomic variables.

The results confirm our prediction that the probability of any health insurance coverage is negatively associated with unemployment rate. We find that a one percentage point increase in the state unemployment rate is associated with a decrease in the probability of health insurance coverage, through any source, of 0.62 percent for men, 0.54 percent for women, and 1.1 percent for children. However, our prediction that an indicator variable for national recession would be negatively correlated with the probability of health insurance coverage is not supported by the data. We find that changes in employment status explain roughly one-quarter of the correlation between health insurance coverage and unemployment rates. Our estimates imply that 440,000 men, 436,000 women, and 494,000 children have lost health insurance coverage during the current recession. 


\section{Introduction}

In March 2001, the longest economic expansion in U.S. history ended, and an economic recession began. ${ }^{1}$ It is not yet known how the current recession has affected the number of Americans lacking health insurance. The primary objective of this paper is to improve our understanding of the historical relationship between state and national macroeconomic climate and the health insurance coverage of Americans. The secondary objective of this paper is to use the historical findings to predict how rates of uninsurance may change during the current U.S. recession.

Economic recession may increase the numbers of Americans lacking health insurance through several pathways. The first two involve reduced numbers of people with employer-provided health insurance. Table 4.1 lists the sources of insurance coverage for U.S. adults in 2000; 83.4 million (50 percent of all) adult Americans receive health insurance through their employer, and an additional 31.1 million (19 percent) receive it through the employer of a parent or spouse.

The first route by which recession may increase rates of uninsurance is by the newly unemployed losing health insurance provided by their previous employers. Although the Consolidated Omnibus Budget Reconciliation Act (COBRA) of 1985 allows eligible unemployed workers to purchase health insurance temporarily through their former employers, ${ }^{2}$ take-up rates under COBRA are low. ${ }^{3}$ In the majority of cases, the loss of employment involves the loss of any health insurance the

Table 4.1

Source of insurance coverage for U.S. adults in year $2000^{\mathrm{ab}}$

\begin{tabular}{lcc}
\hline Insurance source & Number (thousands) & Percent \\
\hline Employer: own & 83,385 & 50 \\
Employer: other & 31,148 & 19 \\
Individual & 9,438 & 6 \\
Medicaid & 7,029 & 4 \\
Other & 6,646 & 4 \\
Uninsured & 29,261 & 18 \\
Total & 166,907 & 100 \\
\hline
\end{tabular}

${ }^{a}$ Data: March 2001 Current Population Survey (CPS). CPS respondents were asked to report whether they had some health insurance coverage in the previous year.

bSample includes all U.S. adults age 18 to 64 .

Source: Lambrew (2001), Appendix Table 1. 
worker received from the former employer. However, some who lose their jobs remain covered by insurance provided by a spouse's employer. Overall, 44 percent of those who lose their jobs become uninsured as a result. ${ }^{4}$ Families USA estimates that between the time the current recession began in March 2001 and December 2001, 1.04 million newly unemployed workers lost health insurance coverage. After adding the spouses and children of workers who lost their jobs, they estimate that a total of 2.02 million persons lost health insurance coverage due to unemployment. ${ }^{5}$

Second, recession may be accompanied by reduced health insurance coverage of those who remain employed. Employers may cease offering health insurance to cut costs in the face of falling profits. Alternatively, employers may reduce their contributions and shift health insurance costs to employees, causing additional employees to decline coverage. In addition, full-time workers may be shifted to part-time jobs that no longer qualify for health insurance benefits.

The third pathway by which recession may affect the number of the uninsured is that state governments may reduce eligibility for publicly provided health insurance. Table 4.1 indicates that 7 million (4 percent of all) U.S. adults receive health insurance coverage through Medicaid. Medicaid spending is a large share of state budgets (on average, 15 percent $)^{6}$ so when state tax revenues fall due to recession, there is increased pressure to cut Medicaid budgets, potentially increasing the number of Medicaid-eligible individuals left without coverage. State governors have recently proposed numerous cuts in response to the current recession, including cuts in payments to providers. ${ }^{7}$ Those covered by the State Children's Health Insurance Plan (SCHIP) may also be vulnerable to state budget cuts. Medicaid and SCHIP cover 15 percent of unemployed women and 53 percent of children with unemployed parents. ${ }^{8}$ Two factors add to the current pressure on state governments to cut public health insurance programs: first, many states increased eligibility for public health insurance during the 1990s, when state budget prospects were brighter, and second, health care costs appear to be increasing as a fraction of GDP after nearly nine years of stability. ${ }^{9}$ On the other hand, some people might gain health insurance coverage during recession if their incomes fall to a level that qualifies for Medicaid.

Finally, recession may affect the number of uninsured if those who previously purchased private health insurance become unable to afford it. Table 4.1 indicates that 9.4 million (6 percent of all) adult Americans 
are covered by privately purchased health insurance. As the ranks of the unemployed swell, people who previously were covered through their employer may purchase individual coverage.

Policy makers should be concerned about the loss of health insurance coverage during recession for several reasons. First, some who lose employer provided health insurance will join the rolls of publicly provided health insurance such as Medicaid and SCHIP, increasing the strain on the budgets of those programs. Second, uninsured persons may receive less medical treatment than the insured. ${ }^{10}$ Third, uninsured persons may impose costs on the health care system by receiving their care in relatively inefficient ways, such as using the emergency room. for conditions that could have been treated with an office visit, or being hospitalized for conditions that could have been treated on an outpatient basis. ${ }^{11}$ Fourth, uninsured individuals are at risk of severe financial loss in the event of illness. ${ }^{12}$

The current U.S. recession creates an urgent need to understand the relationship between macroeconomic climate and the health insurance coverage of the U.S. population. Our research will also provide answers to the following questions: How does the effect of the local economic climate on insurance coverage differ for men, women, and children? What aspect of the macroeconomy is correlated with health insurance coverage: unemployment rate or recession? Does the macroeconomic climate primarily affect rates of uninsurance through employment?

\section{Related Literature}

Most studies investigating determinants of insurance status include macroeconomic variables such as state unemployment rate as control variables, but the coefficients on these variables are not the focus of the study and are rarely discussed at any length in the text. Only a few studies focus on the link between macroeconomic conditions and health insurance coverage. A Kaiser Family Foundation brief studied aggregate March Current Population Survey data for 1980-2000 and found that every percentage point rise in unemployment was associated with an increase of 1.2 million uninsured persons. ${ }^{13} \mathrm{~A}$ study by Holahan and Garrett (2001), which is based on Ku and Garrett (2000), estimates that a one percentage point increase in unemployment is associated with a rise in Medicaid enrollment of 1.5 million. Marquis and Long (2001) find mixed evidence that county unemployment rates are 
correlated with employer offers of health insurance and employer contributions to health insurance. They find that employers are more likely to offer health insurance in tight labor markets in 1993, but they cannot reject the hypothesis of a zero correlation in 1997. They also find, contrary to their prediction, that the employer's contribution to employee health insurance is positively correlated with the county unemployment rate.

While few papers have focused on the relationship between local unemployment rates and individual health insurance status, there has been considerable research on the relationship between individual health insurance status and labor force participation. In particular, many researchers have examined the effect of health insurance coverage on hours worked, retirement, or the labor force participation of married or low-income women. ${ }^{14}$ Other recent research has assessed the impact of COBRA and the Health Insurance Portability and Accountability Act (HIPAA) of 1996 on the probability that unemployed individuals have health insurance. ${ }^{15}$ In its focus on macroeconomic conditions as the key independent variables, this paper also relates to recent research that examines the impact of macroeconomic conditions on health status or health behaviors. ${ }^{16}$

\section{Methods}

We first estimate a model in which the dependent variable indicates whether an individual has any health insurance coverage at a particular point in time. The empirical analysis is based on a random utility model. Suppose that each person derives utility based on insurance status; people enjoy utility $U_{\mathbb{N} S}$ if they are insured, and utility $U_{\text {UNINS }}$ if they are uninsured. The utility derived from being insured or uninsured depends on individual characteristics $X$ and macroeconomic conditions $M$ :

$$
\begin{aligned}
& U_{\mathbb{N S}}=\alpha_{\mathbb{N S}}+X \beta_{\mathbb{N N S}}+M \gamma_{\mathbb{N S}}+\varepsilon_{\mathbb{N S}} \\
& U_{\text {UNINS }}=\alpha_{\text {UNINS }}+X \beta_{\text {UNINS }}+M \gamma_{\text {UNINS }}+\varepsilon_{\text {UNNNS }}
\end{aligned}
$$

Macroeconomic conditions may affect the utility of being insured if, for example, recession raises the cost of achieving health insurance coverage.

Let $y=1$ if the individual is insured and $y=0$ if the individual is uninsured. The probability that a person is insured is equal to the 
probability that utility in the insured state exceeds utility in the uninsured state.

$$
\begin{aligned}
\operatorname{Pr}[y=1]= & \operatorname{Pr}\left[U_{\mathbb{N N S}}>U_{\text {UNINS }}\right] \\
\operatorname{Pr}[y=1]= & \operatorname{Pr}\left[\left(\varepsilon_{\mathbb{N N S}}-\varepsilon_{\text {UNINS }}\right)>-\left(\alpha_{\mathbb{I N S}}-\alpha_{\text {UNNNS }}\right)\right. \\
& \left.-X\left(\beta_{\mathbb{I N S}}-\beta_{\text {UNINS }}\right)-M\left(\gamma_{\mathbb{N N S}}-\gamma_{\text {UNINS }}\right)\right] \\
\operatorname{PR}[y=1]= & \operatorname{Pr}[\varepsilon>-\alpha-X \beta-M \gamma]
\end{aligned}
$$

The distribution of the differenced error term determines the proper regression model to use when estimating the probability of health insurance coverage of individual $i$ living in state $s$ at time $t$ as a function of macroeconomic conditions $M$ and individual characteristics $X$. This paper assumes that the differenced error term follows a binomial distribution; as a result, linear probability models will be estimated.

$$
y_{i s t}=\alpha+X_{i t} \beta+M_{s t} \gamma+\varepsilon_{i s t}
$$

Macroeconomic conditions include state unemployment rates at the state level and an indicator variable that equals 1 if time $t$ is during an economic recession; a set of indicator variables for year are also included. Individual-specific fixed effects are removed. Individual characteristics $X$ include time-varying factors that may affect the person's probability of being uninsured, including age, marital status, education, and family size.

The parameters of interest are the $\gamma$ coefficients, which will be used to measure the change in the probability that individuals lack health insurance coverage associated with the change in macroeconomic variables. The hypothesis of this paper is that national recession and higher unemployment are associated with lower probabilities of overall health insurance coverage. Models similar to equation (4.1) will also be estimated for the following dependent variables: an indicator for whether one receives health insurance coverage through one's current employer, an indicator for whether one's current employer offers health insurance, an indicator for whether one receives health insurance coverage through the employer of one's spouse, an indicator for whether one has privately purchased health insurance coverage, an indicator for whether the individual is covered by governmentprovided health insurance, an indicator for whether one's children are covered by health insurance through any source, and an indicator for whether one's children are covered through government-provided health insurance. 
We predict that the coefficients on variables for macroeconomic conditions will have the following sign, depending on the dependent variable (the source of the health insurance). Higher unemployment rates and national recession are assumed to decrease the probability of coverage through any source, any employer, and one's own employer because a higher unemployment rate implies both increased numbers of individuals lacking jobs and lower total compensation (wages plus benefits). We do not have unambiguous predictions about the signs of the coefficients on macroeconomic variables in the regressions for coverage through spouse's employer, privately purchased plans, or the government because there are potentially offsetting effects. Higher unemployment rates and recession may lead to the loss of the spouse's job but may also lead to the loss of one's own job and switching to coverage through the spouse's employer. Likewise, such changes in the macroeconomy may increase the probability of privately purchased coverage because people lose their employer-provided coverage and begin to purchase it privately, but they could also make such coverage less affordable. Similarly, such changes may increase the probability of coverage through the government because people's incomes fall to the point where they qualify for Medicaid, or it may lead state legislatures to tighten eligibility requirements to decrease the Medicaid rolls.

To determine the extent to which macroeconomic conditions affect health insurance coverage through all mechanisms, we first estimate model (1) with only the demographic characteristics and macroeconomic conditions included as regressors. Change in employment status is one important route by which macroeconomic conditions affect health insurance; we estimate the probability of employment as a function of demographic characteristics and macroeconomic conditions. Finally, we re-estimate model (1) by controlling for employment status.

\section{Data}

The relationship between state and national economic climate and individuals' health insurance status is measured using data from two nationally representative samples: the Survey of Income and Program Participation (SIPP) and the National Longitudinal Survey of Youth (NLSY). ${ }^{17}$ Each of the data sets is well suited for a study of health insurance and the macroeconomy because they both follow the same individuals over a considerable period of time, enabling us to remove 
individual fixed effects. An advantage of the SIPP is its large sample size, and the advantages of the NLSY are its rich information about labor market experience and a larger set of questions about health insurance. In most cases, the SIPP will serve as the primary data set, and the NLSY estimates will be used as a robustness check.

The Survey of Income and Program Participation

The Survey of Income and Program Participation (SIPP) is a nationally representative sample of Americans over the age of fifteen ${ }^{18}$ and consists of a series of four-year panels starting in 1984, with sample sizes ranging from approximately 14,000 to 36,700 households. The SIPP interviews households at four-month intervals (collecting data on the current month and, retrospectively, each of the three months between interviews) for up to four years. Each wave contains information on the source of health insurance coverage during each month, as well as periods of uninsurance over the last twelve months. The SIPP also contains information on job status and demographic characteristics that influence the choice of insurance status (e.g., age, race, gender, education, marital status, and family size). Publicly available state identifiers permit the merger of macroeconomic variables with the SIPP data. This paper uses data from the 1990-1996 panels of the SIPP, covering the period 1990-1999. Summary statistics of the SIPP data appear in table 4.2. To avoid recall bias, we do not use the retrospective data; instead, we focus exclusively on data collected for the current month in which the respondent is interviewed.

\section{The National Longitudinal Survey of Youth}

The National Longitudinal Survey of Youth (NLSY) contains data from interviews of 12,686 respondents conducted annually from 1979 to 1994 and every two years from 1994 to 2000 . We use data from 1983-2000 on whether the respondent's primary employer offers health insurance coverage. In the 1989-2000 interviews, respondents were also asked whether they, their spouse, and their children are currently covered by health insurance; the source of the insurance was also recorded. The NLSY contains a rich set of information about the respondents' labor force activity and human capital. Restricted-access geocodes permit the merger of macroeconomic variables with the NLSY data. Summary statistics of the NLSY data appear in table 4.3. 


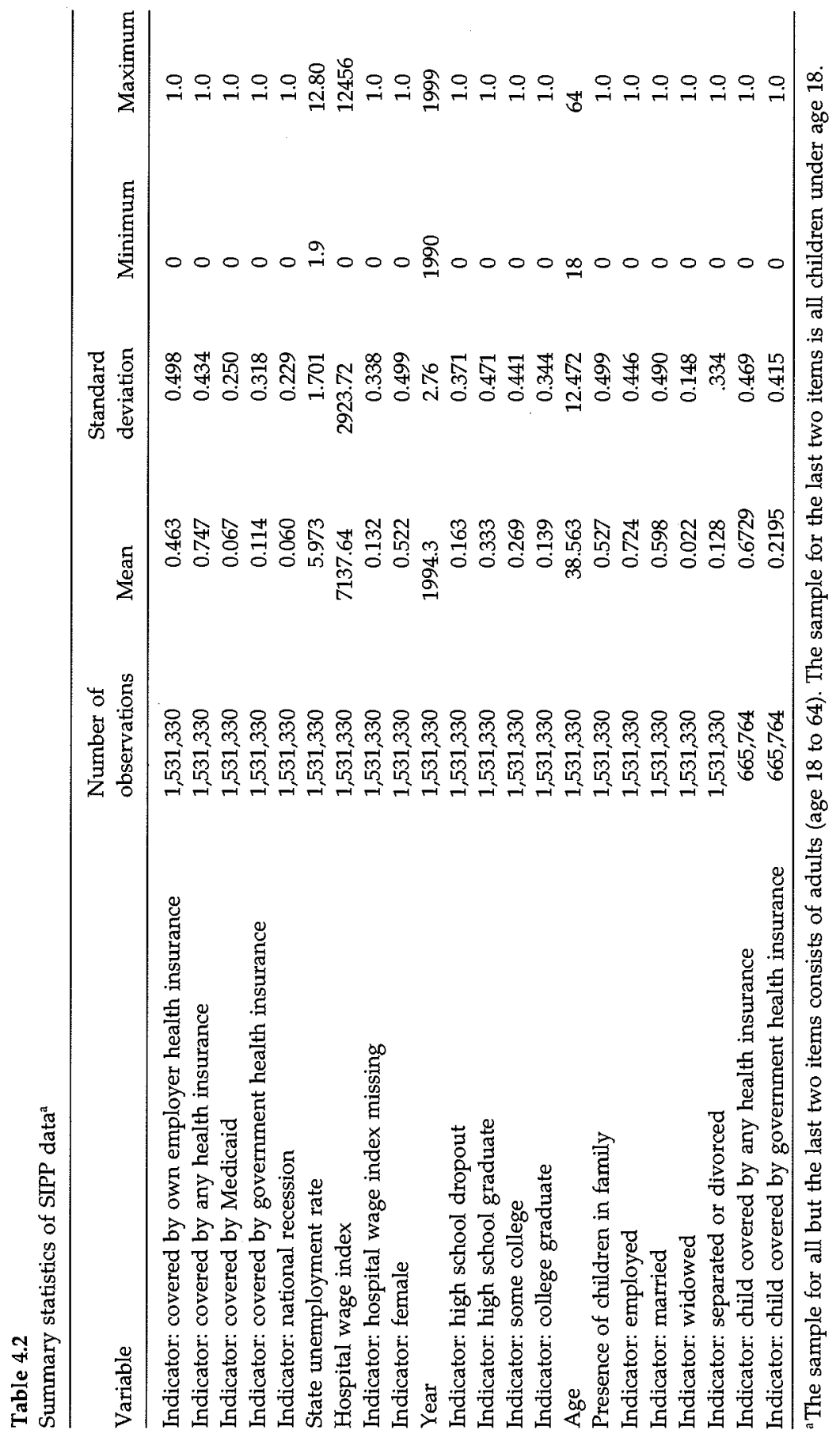




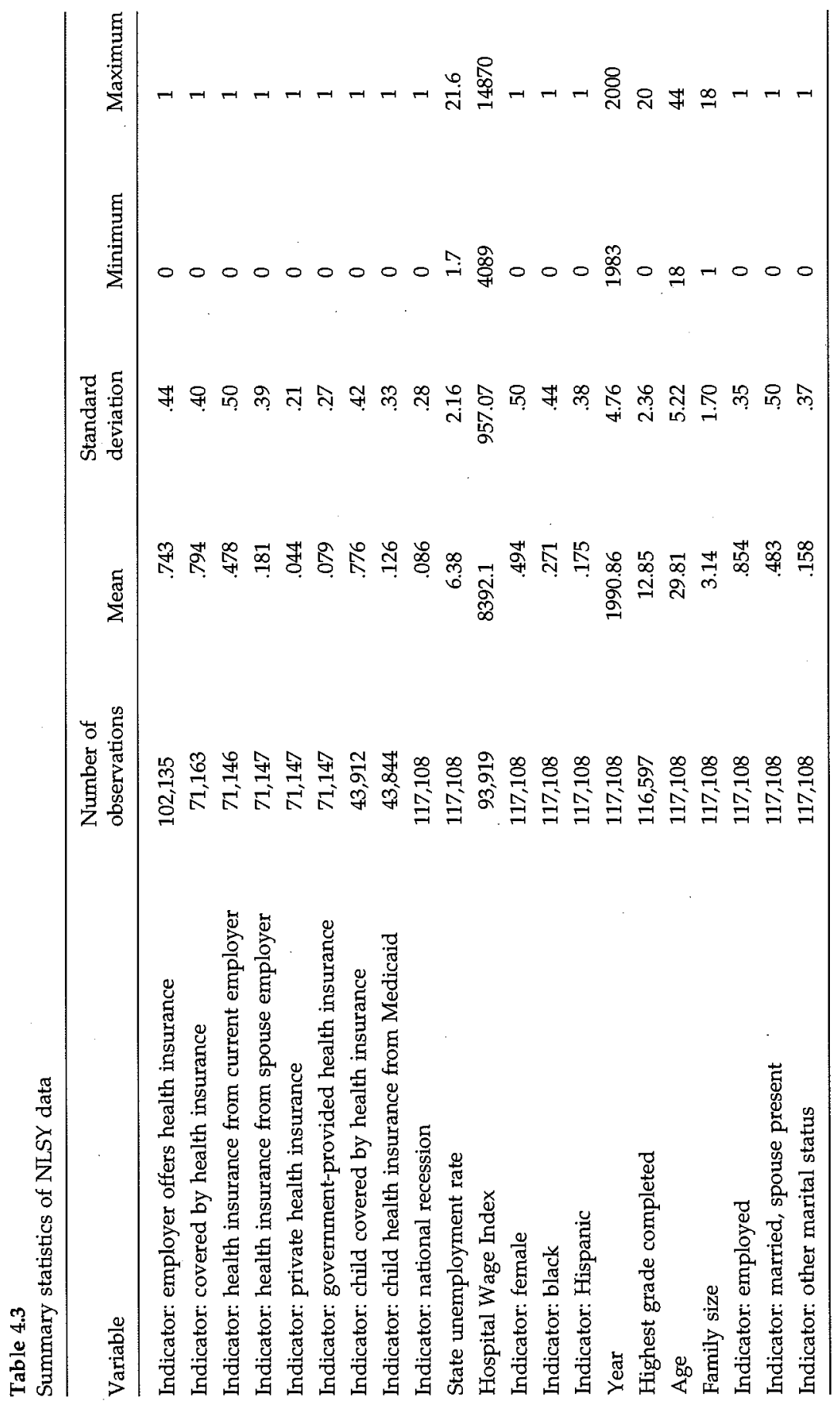




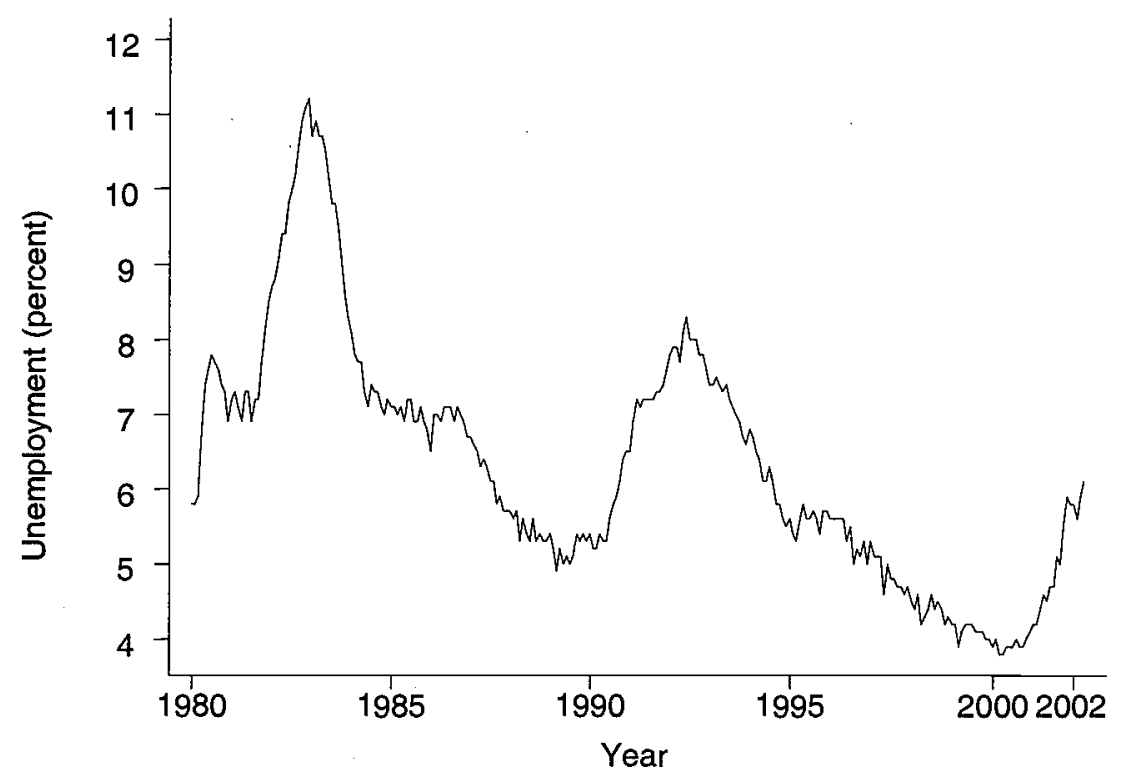

Figure 4.1

U.S. monthly unemployment rate (seasonally adjusted), 1980-2002

Source: Bureau of Labor Statistics, Local Area Unemployment Statistics Series.

Data on Macroeconomic Conditions

The key explanatory variables that reflect the economic climate are the monthly state unemployment rate and an indicator variable for national recession. The Bureau of Labor Statistics Local Area Unemployment Statistics Series is the source for monthly unemployment rates at the state level. Figure 4.1 plots national monthly unemployment. We identify the effect of state unemployment rate on rates of uninsurance using individual-specific variation over time in unemployment rate. This individual-specific variation occurs in two possible ways: first, when individuals move between states that differ in their unemployment rate, and second, when individuals remain in the same state but the unemployment rate in that state varies over time. To illustrate the variation across states in mean unemployment rate and variation of unemployment rate within states over time, figure 4.2 depicts the mean of the state unemployment rate during the period covered by our data (1983 to 2000 ) and figure 4.3 depicts its variance. 


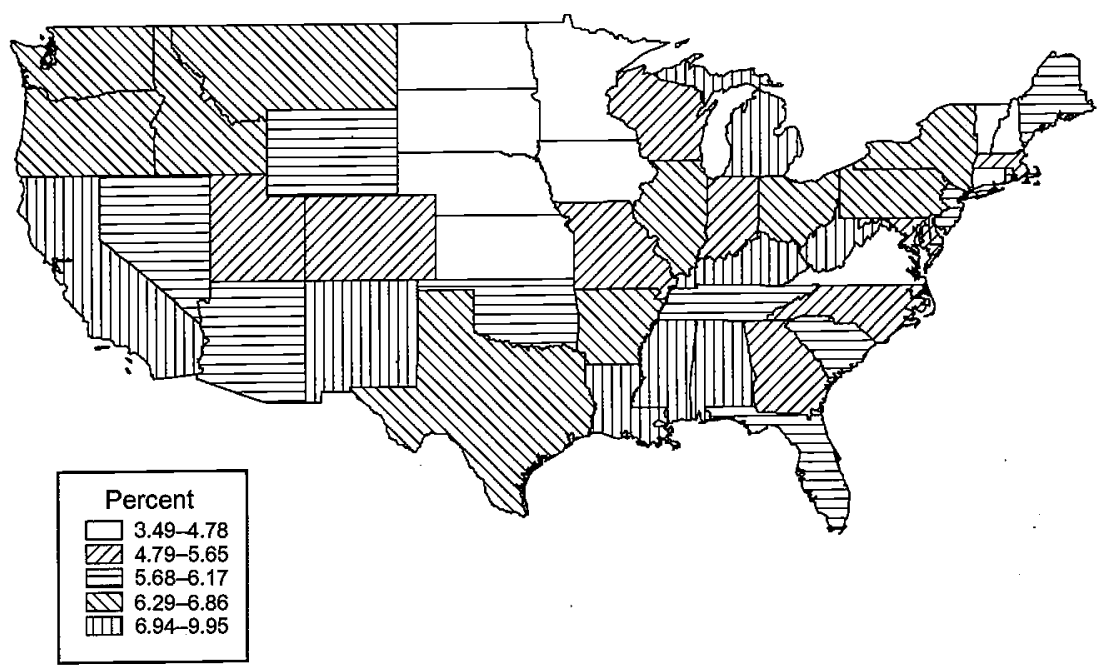

Figure 4.2

Mean state unemployment rate, 1983-2000

We also include as a regressor an indicator variable for whether the United States was in economic recession. The coding of this variable is based on the decisions of the Business Cycle Dating Committee of the National Bureau of Economic Research (NBER). Recession is sometimes casually defined as two consecutive quarters of declining real gross national product, but the NBER defines recession as "a period of significant decline in total output, income, employment, and trade, usually lasting from six months to a year, and marked by widespread contractions in many sectors of the economy."19 Table 4.4 lists the NBER's business cycle reference dates since World War II. The peaks in the unemployment rate in figure 4.1 tend to occur after the recessions listed in table 4.4 because unemployment rate is a lagging indicator of recession. ${ }^{20}$ The final row of table 4.4 indicates that the previous expansion (the longest on record) lasted from March 1991 to March 2001. The NBER has not yet determined the date of the trough (i.e., the end date) of the current recession. ${ }^{21}$ The data used in this paper allow study of uninsurance during the previous recession, which lasted from July 1990 to March 1991.

Ideally we would know the cost of private health insurance over geographic regions and time. Instead, the Medicare Hospital Input Price Index is used as a proxy for differences in the cost of health insurance. 


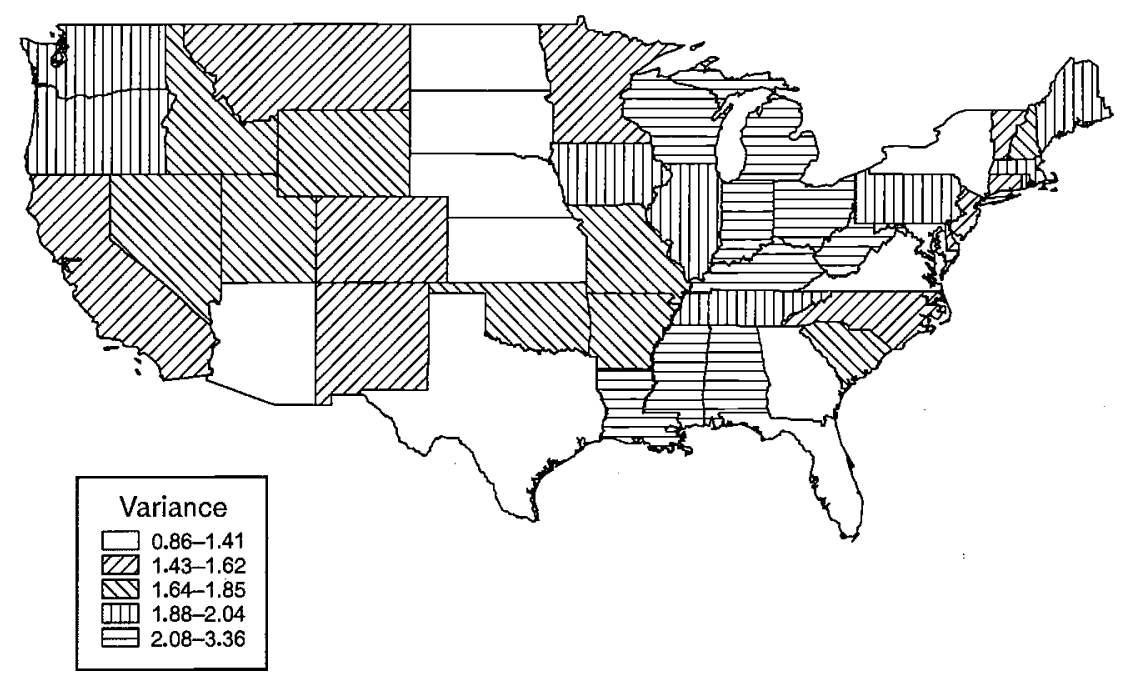

Figure 4.3

Variance state unemployment rate, 1983-2000

\section{Empirical Results}

The probability that an individual has health insurance coverage is first estimated as a function of macroeconomic conditions and basic demographic characteristics. Table 4.5 contains results for males in the SIPP, and table 4.6 contains results for males in the NLSY. In the first two columns of table 4.5 , our prediction regarding unemployment rate is confirmed, while that for the recession indicator is not. Table 4.5 indicates that a one percentage point increase in the state unemployment rate is associated with a 0.62 percent decrease in the probability that a SIPP male is covered by health insurance through any source and a 0.8 percent decrease in the probability of coverage through an employer. In table 4.5 , the indicator variable for national recession also has a positive and statistically significant coefficient, implying that during recession men are 0.4 percent more likely to have health insurance through any source and 0.51 percent more likely to be covered by an employer. The surprising sign on the indicator for national recession may be the result of multicollinearity between unemployment and recession. In the third and fourth columns of table 4.5, which correspond to government-provided coverage, the signs of the coefficients on unemployment rate are opposite to those in the first two 


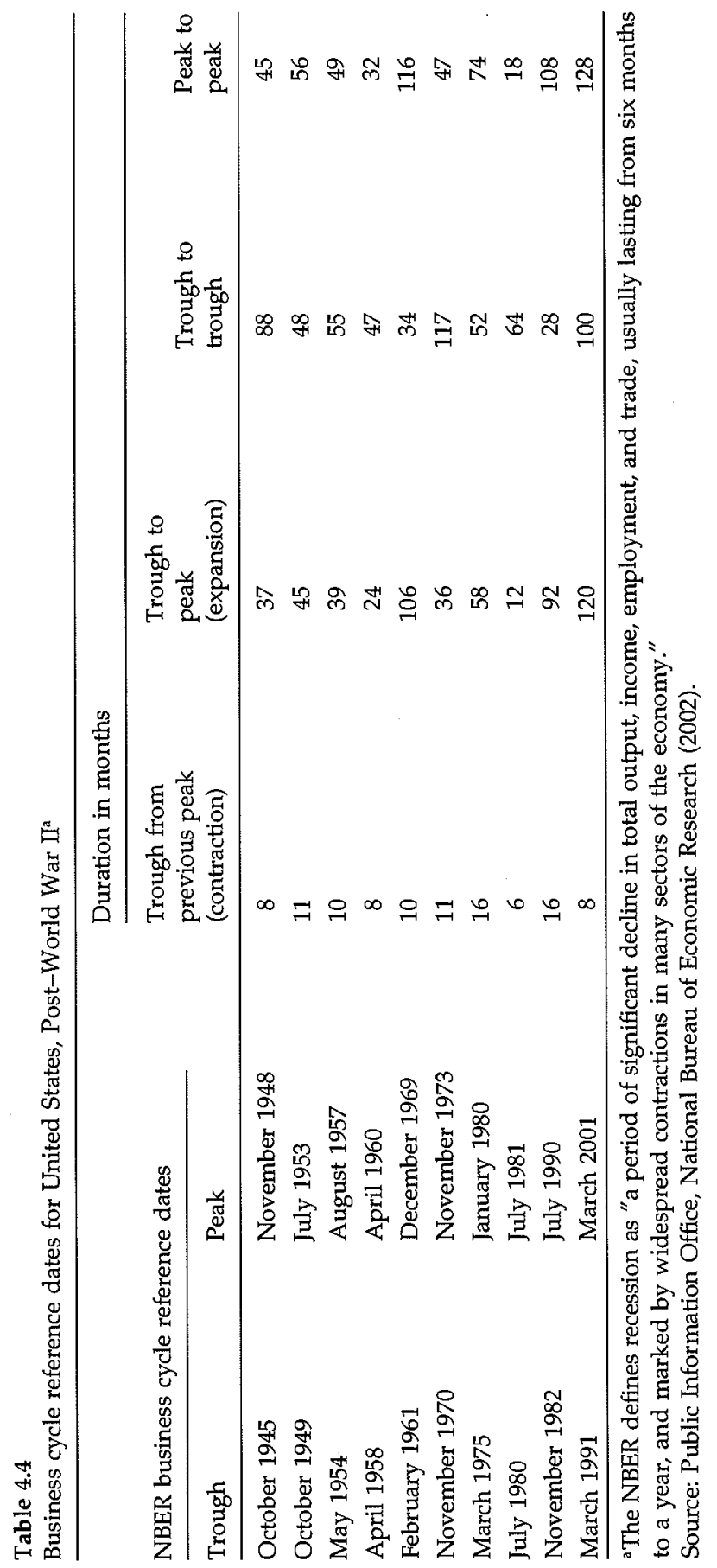


Table 4.5

SIPP men, whether covered by health insurance as a function of macroeconomic conditions: linear probability coefficients and $t$ statistics ${ }^{\mathrm{a}} \mathrm{c}$

\begin{tabular}{lllll}
\hline Macroeconomic variable & $\begin{array}{l}\text { Any } \\
\text { source }\end{array}$ & $\begin{array}{l}\text { Employer } \\
\text { coverage }\end{array}$ & Medicaid & $\begin{array}{l}\text { Government } \\
\text { provided }\end{array}$ \\
\hline Indicator: national recession & .0040 & .0051 & -.0017 & -.0019 \\
& $(2.15)$ & $(2.35)$ & $(-1.89)$ & $(-1.57)$ \\
State unemployment rate & -.0062 & -.0080 & .0021 & .0028 \\
& $(-12.03)$ & $(-13.40)$ & $(8.87)$ & $(8.48)$ \\
Number of observations & 731,311 & 731,311 & 731,311 & 731,311 \\
\hline
\end{tabular}

a Data: pooled 1990-1996 waves of the SIPP. Sample includes all individuals between the age of 17 and 64, regardless of employment status.

b Dependent variables: column 1 -indicator variable that equals 1 if the individual is covered by health insurance from any source and 0 otherwise; column 2 -indicator variable that equals 1 if the individual is covered by employer health insurance in own name and 0 otherwise; column 3-indicator variable for Medicaid coverage; column 4-indicator variable for any type of government-provided health insurance.

'Other regressors: individual fixed effects, year indicators, Medicare hospital wage index, highest grade completed, marital status, presence of children in the family, and age.

Table 4.6

NLSY men, whether covered by health insurance as a function of macroeconomic conditions: linear probability coefficients and $t$ statistics $^{\mathrm{abc}}$

\begin{tabular}{|c|c|c|c|c|c|}
\hline Macroeconomic variable & $\begin{array}{l}\text { Any } \\
\text { source }\end{array}$ & $\begin{array}{l}\text { Own } \\
\text { current } \\
\text { employer }\end{array}$ & $\begin{array}{l}\text { Spouse's } \\
\text { current } \\
\text { employer }\end{array}$ & $\begin{array}{l}\text { Privately } \\
\text { purchased }\end{array}$ & $\begin{array}{l}\text { Government } \\
\text { provided }\end{array}$ \\
\hline Indicator: national recession & $\begin{array}{l}.0098 \\
(0.17)\end{array}$ & $\begin{array}{l}-.0620 \\
(-0.97)\end{array}$ & $\begin{array}{l}.0616 \\
(1.54)\end{array}$ & $\begin{array}{l}-.0065 \\
(-0.20)\end{array}$ & $\begin{array}{l}.0430 \\
(1.69)\end{array}$ \\
\hline State unemployment rate & $\begin{array}{l}-.0014 \\
(-0.60)\end{array}$ & $\begin{array}{l}-.0057 \\
(-2.26)\end{array}$ & $\begin{array}{l}-.0001 \\
(-0.08)\end{array}$ & $\begin{array}{l}.0041 \\
(3.12)\end{array}$ & $\begin{array}{l}.0016 \\
(1.56)\end{array}$ \\
\hline Number of observations & 34,677 & 34,677 & 34,677 & 34,677 & 34,677 \\
\hline
\end{tabular}

aData: eight pooled years of the NLSY. Sample includes the employed and those not employed.

bDependent variables: column 1 -indicator variable that equals 1 if the individual has health insurance coverage from any source and 0 otherwise; column 2-indicator variable that equals 1 if the individual has health insurance coverage through his or her current employer and 0 otherwise; column 3-indicator variable that equals 1 if the individual has health insurance coverage through spouse's current employer and 0 otherwise; column 4-indicator variable that equals 1 if the individual has privately purchased health insurance coverage and 0 otherwise; column 5-indicator variable that equals 1 if the individual has government-provided health insurance coverage and 0 otherwise.

'Other regressors: individual fixed effects, year indicators, Medicare hospital wage index, highest grade completed, age, family size, and indicator variables for marital status. 
Table 4.7

SIPP women, whether covered by health insurance as a function of macroeconomic conditions: linear probability coefficients and $t$ statistics $^{\mathrm{ab}} \mathrm{c}$

\begin{tabular}{lllll}
\hline Macroeconomic variable & $\begin{array}{l}\text { Any } \\
\text { source }\end{array}$ & $\begin{array}{l}\text { Employer } \\
\text { coverage }\end{array}$ & Medicaid & $\begin{array}{l}\text { Government } \\
\text { provided }\end{array}$ \\
\hline Indicator: national recession & .0030 & .0005 & -.0017 & -.0007 \\
State unemployment rate & $(1.67)$ & $(0.30)$ & $(-1.48)$ & $(-0.49)$ \\
& -.0054 & -.0026 & .0037 & .0032 \\
Number of observations & $(-11.04)$ & $(-4.72)$ & $(11.45)$ & $(8.51)$ \\
\hline
\end{tabular}

a Data: pooled 1990-1996 waves of the SIPP. Sample includes all individuals between the age of 17 and 64, regardless of employment status.

${ }^{b}$ Dependent variables: column 1-indicator variable that equals 1 if the individual is covered by health insurance from any source and 0 otherwise; column 2-indicator variable that equals 1 if the individual is covered by employer health insurance in own name and 0 otherwise; column 3 -indicator variable for Medicaid coverage; column 4-indicator variable for any type of government-provided health insurance.

'Other regressors: individual fixed effects, year indicators, Medicare hospital wage index, highest grade completed, marital status, presence of children in the family, and age.

columns; higher unemployment is associated with a higher probability of government-provided coverage for SIPP males. Specifically, a one percentage point rise in unemployment is associated with a 0.21 percent increase in the probability that an adult male is covered by Medicaid and a 0.28 percent increase in the probability of coverage through some government program. In table 4.6, which corresponds to males in the NLSY, the coefficients are generally not statistically significant. The exceptions are that a one percentage point increase in the state unemployment rate is associated with a 0.57 percent lower probability of coverage through one's own employer and a 0.41 percent higher probability of privately purchased coverage.

Table 4.7 contains results for females in the SIPP, and table 4.8 contains results for females in the NLSY. The results for SIPP women in table 4.7 imply that a one percentage point rise in the local unemployment rate is associated with a 0.54 percent decrease in the probability that a woman has coverage through any source, and a 0.26 percent decrease in the probability of coverage through an employer. There are some major gender differences in the results for the SIPP. The coefficient on the indicator variable for national recession is generally statistically significant for the SIPP men in table 4.5 , but it is not statistically significant for the SIPP women in table 4.7. 


\section{Table 4.8}

NLSY women, whether covered by health insurance as a function of macroeconomic conditions: linear probability coefficients and $t$ statistics ${ }^{\text {b c }}$

\begin{tabular}{|c|c|c|c|c|c|}
\hline Macroeconomic variable & $\begin{array}{l}\text { Any } \\
\text { source }\end{array}$ & $\begin{array}{l}\text { Own } \\
\text { current } \\
\text { employer }\end{array}$ & $\begin{array}{l}\text { Spouse's } \\
\text { current } \\
\text { employer }\end{array}$ & $\begin{array}{l}\text { Privately } \\
\text { purchased }\end{array}$ & $\begin{array}{l}\text { Government } \\
\text { provided }\end{array}$ \\
\hline Indicator: national recession & $\begin{array}{l}.0710 \\
(0.90)\end{array}$ & $\begin{array}{l}.0125 \\
(0.14)\end{array}$ & $\begin{array}{l}.1049 \\
(1.35)\end{array}$ & $\begin{array}{l}.0241 \\
(0.56)\end{array}$ & $\begin{array}{l}.0362 \\
(0.64)\end{array}$ \\
\hline State unemployment rate & $\begin{array}{l}.0031 \\
(1.47)\end{array}$ & $\begin{array}{l}-.0013 \\
(-0.55)\end{array}$ & $\begin{array}{l}-.0043 \\
(-2.08)\end{array}$ & $\begin{array}{l}.0018 \\
(1.54)\end{array}$ & $\begin{array}{l}.0067 \\
(4.49)\end{array}$ \\
\hline Number of observations & 36,465 & 36,465 & 36,465 & 36,465 & 36,465 \\
\hline
\end{tabular}

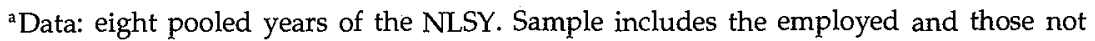
employed.

${ }^{b}$ Dependent variables: column 1 -indicator variable that equals 1 if the individual has health insurance coverage from any source and 0 otherwise; column 2 -indicator variable that equals 1 if the individual has health insurance coverage through her or his current employer and 0 otherwise; column 3-indicator variable that equals 1 if the individual has health insurance coverage through spouse's current employer and 0 otherwise; column 4 -indicator variable that equals 1 if the individual has privately purchased health insurance coverage and 0 otherwise; column 5-indicator variable that equals 1 if the individual has government-provided health insurance coverage and 0 otherwise.

'Other regressors: individual fixed effects, year indicators, Medicare hospital wage index, highest grade completed, age, family size, and indicator variables for marital status.

In table 4.7 , the coefficient signs on the unemployment rate in the last two columns are opposite to those in the first two columns; higher unemployment is associated with a higher probability of governmentprovided coverage for SIPP females. Specifically, a one percentage point rise in the unemployment rate is associated with a 0.37 percent increase in the probability that an adult female is covered by Medicaid and a 0.32 percent increase in the probability of coverage through some government program. In table 4.8 , which corresponds to females in the NLSY, the coefficients are generally not statistically significant. The exception is that a one percentage point increase in the unemployment rate is associated with a 0.43 percent decrease in the probability that an adult woman is covered through a husband's employer, and a 0.67 percent increase in the probability of coverage through a government program.

Tables 4.9 and 4.10 describe the relationship between macroeconomic conditions and the health insurance coverage of children in the SIPP and the NLSY. In Table 4.9, a one percentage point increase in 


\section{Table 4.9}

SIPP, whether child has health insurance coverage as a function of macroeconomic conditions: linear probability coefficients and $t$ statistics $^{\mathrm{a} b c}$

\begin{tabular}{|c|c|c|c|}
\hline $\begin{array}{l}\text { Macroeconomic } \\
\text { variable }\end{array}$ & $\begin{array}{l}\text { Child has any } \\
\text { coverage }\end{array}$ & $\begin{array}{l}\text { Child has } \\
\text { government- } \\
\text { provided } \\
\text { coverage }\end{array}$ & $\begin{array}{l}\text { Child has } \\
\text { Medicaid } \\
\text { coverage }\end{array}$ \\
\hline Indicator: national recession & $\begin{array}{l}.0058 \\
(3.01)\end{array}$ & $\begin{array}{l}-.0036 \\
(-2.12)\end{array}$ & $\begin{array}{l}-.0039 \\
(-2.41)\end{array}$ \\
\hline State unemployment rate & $\begin{array}{l}-.011 \\
(-21.69)\end{array}$ & $\begin{array}{l}.0078 \\
(16.43)\end{array}$ & $\begin{array}{l}.0078 \\
(17.17)\end{array}$ \\
\hline Number of observations & 702,599 & 702,599 & 702,599 \\
\hline
\end{tabular}

aData: pooled 1990-1996 waves of the SIPP.

${ }^{b}$ Dependent variables: column 1-indicator variable that equals 1 if the child is covered by health insurance from any source and 0 otherwise; column 2-indicator variable that equals 1 if the child has government-provided health insurance coverage and 0 otherwise; column 3-indicator variable that equals 1 if child covered by Medicaid and 0 otherwise.

'Other regressors: individual fixed effects, year indicators, Medicare hospital wage index, and age.

\section{Table 4.10}

NLSY, whether child has health insurance coverage as a function of macroeconomic conditions: linear probability coefficients and $t$ statistics $^{\mathrm{abc}}$

\begin{tabular}{lll}
\hline Macroeconomic variable & $\begin{array}{l}\text { Child has any } \\
\text { coverage }\end{array}$ & $\begin{array}{l}\text { Child has government- } \\
\text { provided coverage }\end{array}$ \\
\hline Indicator: national recession & .0313 & .0433 \\
State unemployment rate & $(0.50)$ & $(0.75)$ \\
& .0009 & .0033 \\
Number of observations & $(0.52)$ & $(2.04)$ \\
\hline
\end{tabular}

${ }^{a}$ Data: eight pooled years of the NLSY.

${ }^{b}$ Dependent variables: column 1 -indicator variable that equals 1 if the child has health insurance coverage from any source and 0 otherwise; column 2-indicator variable that equals 1 if the child has government-provided health insurance coverage and 0 otherwise.

'Other regressors: individual fixed effects, year indicators, Medicare hospital wage index, highest grade completed, age, family size, and marital status of the reporting parent. 
the state unemployment rate is associated with a 1.1 percent decrease in the probability that the child is covered, and a 0.78 percent increase in the probability that the child is covered through the government. During a recession, coverage from any source is 0.58 percent more likely, but coverage through the government is 0.36 percent less likely, conditional on the state unemployment rates. ${ }^{22}$ In Table 4.10 , state unemployment is uncorrelated with the probability that an NLSY child has coverage through any source, but a 1 percent increase in the unemployment rate increases the probability of coverage through the government by 0.33 percent.

An important way that the macroeconomy affects individuals' health insurance status is through their employment status. The remainder of the paper is devoted to determining the extent to which the earlier results (that are not conditioned on employment status) are in fact driven by changes in employment status.

Tables 4.11 and 4.12 contain the results of regressions in which the dependent variable is an indicator variable that equals 1 if the respondent is currently employed. For both women and men in the SIPP and NLSY, individuals are, predictably, less likely to be employed when state or local unemployment rates are high. In the SIPP, a one percentage point rise in the local unemployment rate is associated with a 0.96 percent decrease in the probability of employment for men, and a 0.84 percent decrease for women. In the NLSY, a one percentage point rise in the local unemployment rate is associated with a 0.64 percent de-

\section{Table 4.11}

SIPP, whether currently employed as a function of macroeconomic conditions: linear probability coefficients and $t$ statistics $^{\mathrm{b} c \mathrm{c}}$

\begin{tabular}{lll}
\hline Macroeconomic variable & Men & Women \\
\hline Indicator: national recession & -.005 & .0007 \\
& $(-2.66)$ & $(0.33)$ \\
State unemployment rate & -.0096 & -.0084 \\
& $(-16.85)$ & $(-14.94)$ \\
Number of observations & 731,311 & 800,019 \\
\hline
\end{tabular}

${ }^{a}$ Data: pooled 1990-1996 waves of the SIPP. Sample includes all individuals between the ages of 17 and 64 , regardless of employment status.

${ }^{b}$ Dependent variable equals 1 if the individual is employed during the survey month and 0 otherwise.

'Other regressors: individual fixed effects, year indicators, Medicare hospital wage index, highest grade completed, marital status, presence of children in the family, and age. 
Table 4.12

NLSY, whether currently employed as a function of macroeconomic conditions: linear probability coefficients and $t$ statistics ${ }^{\mathrm{b} c}$

\begin{tabular}{lll}
\hline Macroeconomic variable & Men & Women \\
\hline Indicator: national recession & .0504 & -.0286 \\
& $(1.22)$ & $(-0.38)$ \\
State unemployment rate & -.0064 & -.0041 \\
& $(-7.36)$ & $(-3.52)$ \\
Number of observations & 59,233 & 57,875 \\
\hline
\end{tabular}

${ }^{a}$ Data: fifteen pooled years of the NLSY. Sample includes the employed and those not employed.

${ }^{b}$ Dependent variable equals 1 if the individual is employed at the time of the survey and 0 otherwise.

'Other regressors: individual fixed effects, year indicators, Medicare hospital wage index, highest grade completed, age, family size, and indicator variables for marital status.

\section{Table 4.13}

NLSY, whether current employer offers health insurance as a function of macroeconomic conditions: linear probability coefficients and $t$ statistics ${ }^{\mathrm{ab}} \mathrm{c}$

\begin{tabular}{lll}
\hline Macroeconomic variable & Men & Women \\
\hline Indicator: national recession & .0534 & .0986 \\
& $(0.76)$ & $(1.00)$ \\
State unemployment rate & -.0073 & -.0026 \\
& $(-5.63)$ & $(-1.90)$ \\
Number of observations & 51,241 & $43 ; 702$ \\
\hline
\end{tabular}

${ }^{a}$ Data: fifteen pooled years of the NLSY. Sample includes only those currently employed.

${ }^{b}$ Dependent variable equals 1 if current employer offers health insurance coverage and 0 otherwise.

'Other regressors: individual fixed effects, year indicators, Medicare hospital wage index, highest grade completed, age, family size, and indicator variables for marital status.

crease in the probability of employment for men, and a 0.41 percent decrease for women. Part of the reason for the discrepancy in the magnitudes between the SIPP and the NLSY may be that the SIPP sample contains older workers, whereas the NLSY is limited to younger workers. Only for SIPP males is the recession indicator significantly correlated with employment; recession is associated with a 0.5 percent decrease in the probability of employment for this group. ${ }^{23}$

The NLSY also asks respondents whether their employer offered them health insurance coverage. The correlation of employer offers of health insurance coverage with macroeconomic conditions for the sample of employed respondents is described in table 4.13. A one per- 
centage point increase in the unemployment rate is associated with a 0.73 percent decrease in the probability that one's employer offers health insurance coverage for males and a 0.26 percent decrease for females.

We also tested for changes in the take-up rates of employer-offered health insurance during periods of high unemployment. Specifically, we regressed an indicator variable for whether one receives health insurance coverage through one's own employer on macroeconomic variables for the sample of NLSY respondents who were employed and were offered health insurance coverage by their employers. The coefficient on unemployment rate was statistically significant for women; a one percentage point increase in the local unemployment rate is associated with a 0.7 percent increase in the probability of takeup for women. The results for men were not statistically significant. ${ }^{24}$

The remainder of this section measures the extent to which macroeconomic conditions are correlated with insurance status conditional on employment status. Tables 4.14 through 4.17 are comparable to tables 4.5 through 4.8 , with the difference that an indicator for employment has been added to the set of regressors. The coefficients on the

Table 4.14

SIPP men, whether covered by health insurance as a function of macroeconomic conditions and employınent status: linear probability coefficients and $t$ statistics ${ }^{\mathrm{ab}} \mathrm{c}$

\begin{tabular}{lllll}
\hline Macroeconomic variable & $\begin{array}{l}\text { Any } \\
\text { source }\end{array}$ & $\begin{array}{l}\text { Employer } \\
\text { coverage }\end{array}$ & Medicaid & $\begin{array}{l}\text { Government } \\
\text { provided }\end{array}$ \\
\hline Indicator: national recession & .0049 & .0065 & -.0021 & -.0025 \\
State unemployment rate & $(2.69)$ & $(3.07)$ & $(-2.443)$ & $(-2.18)$ \\
& -.0045 & -.0055 & 0.0014 & .0016 \\
Indicator: employed & $(-8.94)$ & $(-9.53)$ & $(5.82)$ & $(4.91)$ \\
& .1863 & .2748 & -.0854 & -.1370 \\
Number of observations & $(152.99)$ & $(197.49)$ & $(-148.09)$ & $(-174.09)$ \\
\hline
\end{tabular}

a Data: pooled 1990-1996 waves of the SIPP. Sample includes all individuals between the ages of 17 and 64, regardless of employment status.

'Dependent variables: column 1 -indicator variable that equals 1 if the individual is covered by health insurance from any source and 0 otherwise; column 2-indicator variable that equals 1 if the individual is covered by employer health insurance in his or her own name and 0 otherwise; column 3-indicator variable for Medicaid coverage; column 4-indicator variable for any type of government-provided health insurance.

${ }^{c}$ Other regressors: individual fixed effects, year indicators, Medicare hospital wage index, highest grade completed, marital status, presence of children in the family, and age. 
Table 4.15

NLSY men, whether covered by health insurance as a function of macroeconomic conditions and employment status: linear probability coefficients and $t$ statistics ${ }^{\mathrm{a}} \mathrm{c}$

\begin{tabular}{|c|c|c|c|c|c|}
\hline Macroeconomic variable & $\begin{array}{l}\text { Any } \\
\text { source }\end{array}$ & $\begin{array}{l}\text { Own } \\
\text { current } \\
\text { employer }\end{array}$ & $\begin{array}{l}\text { Spouse's } \\
\text { current } \\
\text { employer }\end{array}$ & $\begin{array}{l}\text { Privately } \\
\text { purchased }\end{array}$ & $\begin{array}{l}\text { Government } \\
\text { provided }\end{array}$ \\
\hline Indicator: national recession & $\begin{array}{l}.0023 \\
(0.04)\end{array}$ & $\begin{array}{l}-.0772 \\
(-1.24)\end{array}$ & $\begin{array}{l}.0625 \\
(1.57)\end{array}$ & $\begin{array}{l}-.0065 \\
(-0.20)\end{array}$ & $\begin{array}{l}.0461 \\
(1.83)\end{array}$ \\
\hline State unemployment rate & $\begin{array}{l}-.0003 \\
(-0.15)\end{array}$ & $\begin{array}{l}-.0036 \\
(-1.49)\end{array}$ & $\begin{array}{l}-.0002 \\
(-0.16)\end{array}$ & $\begin{array}{l}.0041 \\
(3.12)\end{array}$ & $\begin{array}{l}.0011 \\
(1.14)\end{array}$ \\
\hline Indicator: employed & $\begin{array}{l}.1703 \\
(24.40)\end{array}$ & $\begin{array}{l}.3433 \\
(45.68)\end{array}$ & $\begin{array}{l}-.0202 \\
(-4.19)\end{array}$ & $\begin{array}{l}-.00004 \\
(-0.01)\end{array}$ & $\begin{array}{l}-.0714 \\
(-23.44)\end{array}$ \\
\hline Number of observations & 34,677 & 34,677 & 34,677 & 34,677 & 34,677 \\
\hline
\end{tabular}

'Data: eight pooled years of the NLSY. Sample includes the employed and those not employed.

bependent variables: column 1-indicator variable that equals 1 if the individual has health insurance coverage from any source and 0 otherwise; column 2-indicator variable that equals 1 if the individual has health insurance coverage through her or his current employer and 0 otherwise; column 3-indicator variable that equals 1 if the individual has health insurance coverage through spouse's current employer and 0 otherwise; column 4-indicator variable that equals 1 if the individual has privately purchased health insurance coverage and 0 otherwise; column 5 -indicator variable that equals 1 if the individual has government-provided health insurance coverage and 0 otherwise.

'Other regressors: individual fixed effects, year indicators, Medicare hospital wage index, highest grade completed, age, family size, and indicator variables for marital status.

indicator variable for employment are uniformly positive, large, and statistically significant, confirming that employment status has a large impact on the probability of coverage.

Tables 4.14 and 4.16 indicate that, even controlling for employment, the unemployment rate remains correlated with the probability of health insurance coverage. In table 4.5, before controlling for employment status, a one percentage point rise in the unemployment rate was associated with a 0.62 percent decrease in the probability of health insurance coverage for SIPP men. In Table 4.14, after controlling for employment status, the associated decrease is 0.45 percent; about one-quarter of the correlation of men's health insurance coverage with unemployment rates seems to operate through changes of employment status.

A comparison of tables 4.15 and 4.6 indicates that the point estimate of the correlation of the state unemployment rate with coverage through one's own employer drops by about one-third after controlling for employment status. After controlling for employment status, the 
Table 4.16

SIPP women, whether covered by health insurance as a function of macroeconomic conditions and employment status: linear probability coefficients and $t$ statistics ${ }^{a b c}$

\begin{tabular}{lllll}
\hline Macroeconomic variable & $\begin{array}{l}\text { Any } \\
\text { source }\end{array}$ & $\begin{array}{l}\text { Employer } \\
\text { coverage }\end{array}$ & Medicaid & $\begin{array}{l}\text { Government } \\
\text { provided }\end{array}$ \\
\hline Indicator: national recession & .0028 & .0003 & -.0017 & -.0006 \\
State unemployment rate & $(1.64)$ & $(0.20)$ & $(-1.44)$ & $(-.43)$ \\
& -.0040 & .00002 & .0028 & 0.0020 \\
Indicator: employed & $(-6.54)$ & $(.04)$ & $(8.77)$ & $(5.60)$ \\
& .1748 & .3121 & -.11 & -.137 \\
Number of observations & $(172.78)$ & $(284.75)$ & $(-164.66)$ & $(-175.31)$ \\
\hline
\end{tabular}

a Data: pooled 1990-1996 waves of the SIPP. Sample includes all individuals between the ages of 17 and 64, regardless of employment status.

bDependent variables: column 1-indicator variable that equals 1 if the individual is covered by health insurance from any source and 0 otherwise; column 2-indicator variable that equals 1 if the individual is covered by employer health insurance in her or his own name and 0 otherwise; column 3-indicator variable for Medicaid coverage; column 4-indicator variable for any type of government-provided health insurance.

${ }^{c}$ Other regressors: individual fixed effects, year indicators, Medicare hospital wage index, highest grade completed, marital status, presence of children in the family, and age.

coefficient on the unemployment rate is no longer statistically significant. Changes in employment status explain none of the correlation between the unemployment rate and the probability of privately purchased coverage.

Similar results hold for the samples of women. In table 4.7, before controlling for employment status, a one percentage point rise in the unemployment rate was associated with a 0.54 percent decrease in the probability of health insurance coverage for SIPP women. After controlling for employment status, the associated decrease listed in table 4.16 is 0.40 percent. As for the SIPP men, roughly one-quarter of the correlation of women's health insurance status with unemployment rates appears to be due to changes of employment status. In table 4.17, as in table 4.8 , the probability that an NLSY woman is covered by health insurance from any source appears largely unrelated to macroeconomic conditions. The exception is that women are less likely to be covered through their husband's employer when state unemployment rates are high, and this condition is little changed by controlling for the woman's employment status. 
Table 4.17.

NLSY women, whether covered by health insurance as a function of macroeconomic conditions and employment status: linear probability coefficients and $t$ statistics ${ }^{\mathrm{a}} \mathrm{c}$

\begin{tabular}{|c|c|c|c|c|c|}
\hline Macroeconomic variable & $\begin{array}{l}\text { Any } \\
\text { source }\end{array}$ & $\begin{array}{l}\text { Own } \\
\text { current } \\
\text { employer }\end{array}$ & $\begin{array}{l}\text { Spouse's } \\
\text { current } \\
\text { employer }\end{array}$ & $\begin{array}{l}\text { Privately } \\
\text { purchased }\end{array}$ & $\begin{array}{l}\text { Government } \\
\text { provided }\end{array}$ \\
\hline Indicator: national recession & $\begin{array}{l}.0731 \\
(0.93)\end{array}$ & $\begin{array}{l}.0289 \\
(0.33)\end{array}$ & $\begin{array}{l}.1011 \\
(1.30)\end{array}$ & $\begin{array}{l}.0237 \\
(0.55)\end{array}$ & $\begin{array}{l}.0292 \\
(0.53)\end{array}$ \\
\hline State unemployment rate & $\begin{array}{l}.0033 \\
(1.59)\end{array}$ & $\begin{array}{l}.0006 \\
(0.24)\end{array}$ & $\begin{array}{l}-.0047 \\
(-2.31)\end{array}$ & $\begin{array}{l}.0017 \\
(1.49)\end{array}$ & $\begin{array}{l}.0059 \\
(4.02)\end{array}$ \\
\hline Indicator: employed & $\begin{array}{l}.0347 \\
(6.99)\end{array}$ & $\begin{array}{l}.2841 \\
(51.15)\end{array}$ & $\begin{array}{l}-.0661 \\
(-13.53)\end{array}$ & $\begin{array}{l}-.0080 \\
(-2.93)\end{array}$ & $\begin{array}{l}-.1210 \\
(-34.64)\end{array}$ \\
\hline Number of observations & 36,465 & 36,465 & 36,465 & 36,465 & 36,465 \\
\hline
\end{tabular}

${ }^{a}$ Data: eight pooled years of the NLSY. Sample includes the employed and those not employed.

${ }^{b}$ Dependent variables: column 1 -indicator variable that equals 1 if the individual has health insurance coverage from any source and 0 otherwise; column 2-indicator variable that equals 1 if the individual has health insurance coverage through his. or her current employer and 0 otherwise; column 3-indicator variable that equals 1 if the individual has health insurance coverage through spouse's current employer and 0 otherwise; column 4-indicator variable that equals 1 if the individual has privately purchased health insurance coverage and 0 otherwise; column 5-indicator variable that equals 1 if the individual has government-provided health insurance coverage and 0 otherwise.

'Other regressors: individual fixed effects, year indicators, Medicare hospital wage index, highest grade completed, age, family size, and indicator variables for marital status.

\section{Conclusion}

This paper examines how the probability of health insurance coverage varies in response to macroeconomic conditions. The results confirm our prediction that the probability of any health insurance coverage is negatively associated with the unemployment rate. We find that a one percentage point increase in the state unemployment rate is associated with a decrease in the probability of health insurance coverage through any source of 0.62 percent for men, 0.54 percent for women, and 1.1 percent for children.

However, our prediction that an indicator variable for national recession would be negatively correlated with the probability of health insurance coverage was not supported by the data. Controlling for the state unemployment rate, the coefficient on recession has a positive sign for men and children; for women it is not statistically significant. 
Employment status is correlated with both macroeconomic conditions and with the probability of health insurance coverage. Changes in employment status explain roughly one-quarter of the correlation between health insurance coverage and unemployment rates. This paper also finds that employer offers of health insurance are sensitive to the local unemployment rate. Women appear to be more likely to take up employer-offered health insurance when unemployment rates are high.

The longest economic expansion in U.S. history ended March 2001. It is not yet known how the current recession has affected the number of Americans lacking health insurance. Between the beginning of the current recession in March 2001 and August 2002, the national unemployment rate rose from 4.3 percent to 5.7 percent, a total of 1.4 percentage points. ${ }^{25}$ The results of this paper suggest that, conditional on the covariates in the model, the change in the unemployment rate, coupled with the presence of recession, is associated with a rise in the probability that individuals lack health insurance of 0.468 percent for men, 0.456 percent for women, and 0.96 percent for children. Using U.S. Census Bureau population estimates for November 1, 2000, of 94.0 million adult males, 95.6 million adult women, and 51.5 million children in the United States, this prediction implies that roughly 440,000 men, 436,000 women, and 494,000 children (a total of 1.37 million Americans) lost health insurance coverage during the current recession. This number is substantial, but it is less than the Families USA (2002) estimate that slightly over 2 million Americans lost health insurance coverage due to increased unemployment between March and December 2001. ${ }^{26}$

Caution should be exercised when estimates derived from the last recession are used to estimate the impact of the current recession. The last recession was over ten years ago, and several factors have changed that may affect the relationship between the macroeconomy and health insurance coverage. For example, more couples are dual-earners, suggesting that the impact of one spouse losing employer-provided health insurance may be less than in the past.

\section{Notes}

We thank David Cutler, Alan Garber, and conference participants for their helpful comments. We gratefully acknowledge financial support from the Economic Research Initiative on the Uninsured and the Bronfenbrenner Life Course Center Innovative Research Program. Simon gratefully acknowledges support from a W. E. Upjohn Institute minigrant. Please email comments to: jhc38@cornell.edu (Cawley) or kis6@cornell.edu (Simon). 
1. Business Cycle Dating Committee, National Bureau of Economic Research (2002).

2. COBRA stipulates that those who recently worked at firms with more than twenty employees have the option of continuing in their employer's health insurance plan for up to eighteen months by paying (at most) 102 percent of the full premium for active employees. The Commonwealth Fund 2001 Health Insurance Survey found that 65 percent of current workers would be eligible for COBRA if they became unemployed; see Doty and Schoen (2001).

3. Only 20 to 25 percent of those eligible for COBRA exercise the option to extend their health insurance coverage; see Rice (1999). The most common explanation for the low take-up rate is cost; on average, families pay annual premiums of $\$ 7,200$ for coverage through COBRA, which represents up to two-thirds of the average worker's unemployment check; see Lambrew (2001).

4. U.S. Census Bureau (1998).

5. Families USA (2002) calculations based on BLS unemployment data and using Census Bureau methodology.

6. Rowland (2002).

7. Pear and Toner (2002).

8. Lambrew (2001).

9. Levitt et al. (2002).

10. Doyle (2001) exploits auto accidents as natural experiments and finds that auto accident victims who were uninsured received 20 percent less treatment and had 37 percent higher mortality than those who were insured.

11. Weissman, Gastonis, and Epstein (1992).

12. Jacoby, Sullivan, and Warren (2000) find that 45.6 percent of persons filing for bankruptcy either incurred at least $\$ 1,000$ in medical bills not covered by insurance or listed illness or injury as the reason for filing for bankruptcy.

13. Gruber and Levitt (2002).

14. Currie and Madrian (1999) and Gruber (2000) provide comprehensive reviews of this literature.

15. See, for example, Gruber and Madrian (1997).

16. See Ruhm and Black (2001), Dee (2001), Ruhm (2000), and Joyce (1990).

17. The Current Population Survey (CPS) is another data set commonly used to assess the health insurance coverage of Americans. The advantages of the NLSY and SIPP over the CPS are that they track individuals for long periods of time and they record health insurance coverage at a particular point in time. The CPS records whether the individual had health insurance coverage at any time in the past year. Bennefield (1996) finds that CPS respondents tend to underreport health insurance coverage relative to SIPP respondents.

18. There are also interview records for children in the household.

19. Public Information Office, National Bureau of Economic Research (2002).

20. Business Cycle Dating Committee (2002). 


\section{Business Cycle Dating Committee (2002).}

22. In exploratory regressions not reported in the tables of this paper, adding a control for state Medicaid eligibility requirements had very little effect on the point estimates of these coefficients.

23. Part-time workers are often not eligible for employer-provided benefits, including health insurance. To test whether recession affects the probability of part-time employment, we regressed an indicator for part-time employment on macroeconomic conditions and demographic characteristics for employed members of the NLSY sample. A one percentage point increase in the unemployment rate is associated with a 0.39 percent increase in the probability that employment is part-time for men and a 0.85 percent increase in the probability that employment is part-time for women.

24. Cutler (2002) finds that employee take-up rates fell during the 1990s.

25. In the past six recessions, unemployment increased by an average of 1.9 percentage points (Business Cycle Dating Committee 2002).

26. The difference between the estimate of the number of Americans who lost health insurance coverage found in this paper and that of Families USA (2002) is lessened by a difference in methods. Families USA (2002) counted health insurance coverage lost only through job loss, whereas this paper counts coverage lost for any reason.

\section{References}

Bennefield, Robert L. (1996). "A Comparative Analysis of Health Insurance Coverage Estimates: Data from CPS and SIPP," \#9608. Washington, D.C.: Bureau of the Census, U.S. Department of Commerce.

Bureau of Labor Statistics. "Local Area Unemployment Statistics Series, 1980-2002." Washington, D.C.

Business Cycle Dating Committee, National Bureau of Economic Research (2002). "The NBER's Business-Cycle Dating Procedure," August 6.

Currie, Janet, and Brigitte C. Madrian (1999). "Health, Health Insurance, and the Labor Market," in Orley Ashenfelter and David Card (eds.), Handbook of Labor Economics, Volume 3C. New York: Elsevier Science.

Cutler, David (2002). "Employee Costs and the Decline in Health Insurance Coverage," NBER Working Paper \#9036.

Dee, Thomas (2001). "Alcohol Abuse and Economic Conditions: Evidence from Repeated Cross-Sections of Individual-Level Data," Health Economics 10(3):257-270.

Doty, Michelle M., and Cathy Schoen (2001). "Maintaining Health Insurance During a Recession: Findings from The Commonwealth Fund 2001 Health Insurance Survey," issue brief. New York: The Commonwealth Fund, December.

Doyle, Joseph J. (2001). "Does Health Insurance Affect Treatment Decisions and Patient Outcomes? Using Automobile Accidents as Unexpected Health Shocks," unpublished manuscript, University of Chicago.

Families USA (2002). "2 Million Americans Lost Their Health Insurance in 2001: Largest One-Year Increase in Nearly a Decade," press release, February 12. 
Gruber, Jon. (2000). "Health Insurance and the Labor Market," in A. J. Culyer and J. P. Newhouse (eds.), Handbook of Health Economics, Volume 1. New York: Elsevier Science.

Gruber, Jon, and Larry Levitt (2002). "Rising Unemployment and the Uninsured." Menlo Park, Calif:: Kaiser Family Foundation, January.

Gruber, Jon, and Brigitte Madrian (1997). "Employment Separation and Health Insurance Coverage," Journal of Public Economics, 66: 349-382.

Holahan, John, and Bowen Garrett (2001). "Rising Unemployment and Medicaid," Health Policy Online, http: / / www.urban.org/UploadedPDF/410306 HPOnline 1.pdf, October.

Jacoby, Melissa B., Teresa A. Sullivan, and Elizabeth Warren (2000). "Medical Problems and Bankruptcy Filings," Harvard Law School Public Law and Legal Theory Working Paper Series \#008, April.

Joyce, Theodore J. (1990). "A Time-Series Analysis of Unemployment and Health: The Case of Birth Outcomes in New York City," Journal of Health Economics, 8(4):419-436.

Ku, L., and B. Garrett (2000). "How Welfare Reform and Economic Factors Affected Medicaid Participation: 1984-96," Assessing the New Federalism Discussion Paper, Number 00-01. Washington, D.C.: The Urban Institute.

Lambrew, Jeanne M. (2001). "How the Slowing U.S. Economy Threatens Employer-Based Health Insurance." New York: The Commonwealth Fund, November.

Levitt, K., C. Smith, C. Cowan, H. Lazenby, and A. Martin (2002). "Inflation Spurs Health Spending in 2000," Health Affairs, 21(1):172-181.

Marquis, M. Susan, and Stephen H. Long (2001). "Employer Health Insurance and Local Labor Market Conditions," International Journal of Health Care Finance and Economics, 1(3-4):273-292.

Pear, Robert, and Robin Toner (2002). "States Face Hard Choices on Medicaid Cuts," New York Times, January 14, 1.

Public Information Office, National Bureau of Economic Research (2002). "Business Cycle Expansions and Contractions," press release.

Rice, Thomas (1999). "Subsidizing COBRA: An Option for Expanding Health Insurance Coverage." Washington, D.C.: Kaiser Foundation.

Rowland, Diane (2002). "Health Insurance for Unemployed Workers." Unpublished manuscript. Washington, D.C.: Kaiser Commission on Medicaid and the Uninsured.

Ruhm, Christopher J. (2000). "Are Recessions Good for Your Health?" Quarterly Journal of Economics, 65(2):617-650.

Ruhm, Christopher J., and William E. Black (2001). "Does Drinking Really Decrease in Bad Times?" National Bureau of Economic Research Working Paper \#8511.

U.S. Census Bureau (1998). "Dynamics of Economic Well Being: Health Insurance 19931995. Who Loses Coverage and for How Long?" Washington D.C.: U.S. Census Bureau, August.

Weissman, J. S., C. Gastonis, and A. M. Epstein (1992). "Rates of Avoidable Hospitalization by Insurance Status in Massachusetts and Maryland," Journal of the American Medical Association, 268(17):2388-2394. 